\title{
The Impact of Human Capital on Economic Growth: Empirical Evidence from Sudan
}

\author{
Khalafalla Ahmed Mohamed Arabi ${ }^{1} \&$ Suliman Zakaria Suliman Abdalla ${ }^{2}$ \\ ${ }^{1}$ Department of Econometrics \& Social Statistics, Faculty of Economics and Administrative Sciences, University of \\ Bakht Al -Ruda, Sudan \\ ${ }^{2}$ Department of Quantitative Analysis, College of Business Administration, King Saud University, Saudi Arabia \\ Correspondece: Khalafalla Ahmed Mohamed Arabi, Professor of Econometrics, Department of Econometrics \& \\ Social Statistics, Faculty of Economics and Administrative Sciences, University of Bakht Al -Ruda, Sudan. Tel: \\ 249-9-1181-1733. E-mail: khalaf_arabi@yahoo.com
}

Received: December 12, 2012

Accepted: January 18, 2013

Online Published: June 30, 2013

doi:10.5430/rwe.v4n2p43

URL: http://dx.doi.org/10.5430/rwe.v4n2p43

\begin{abstract}
This paper empirically investigates the impact of human capital on economic growth in Sudan for the period 1982-2009 by using a simultaneous equation model that links human capital i.e. school attainment; and investment in education and health to economic growth, total productivity, foreign direct investment, and human development index. Based on three-stage least squares technique, the empirical results of the paper show that quality of the education has a determinant role in the economic growth; health quality factor has a positive impact on economic growth as expected and total factor productivity which mainly represents the state of technology has adverse effect on economic growth and human development due to the obsolete and old fashion technology.
\end{abstract}

Keywords: human capital, economic growth, three-stage least squares, Sudan

\section{Introduction}

The analysis and investigation of the effects of human capital (Note 1) on economic growth has gained an increased interest from economists and policy makers and has been extensively analyzed by researchers over the last few decades. The initial theory regarding this relationship dates back to pioneer work of Mincer (1958), Schultz (1961) and Becker (1962), who believes that human capital is just like physical capital and one can invest in it by means of education, health and training which, in turn, will raise output and contribute to economic growth. Accordingly, it is widely accepted that human capital can be considered as one of the main determinants of economic growth (see Mankiw et al, 1992; Barro, 2001), and also it has been identified as a key element in strengthening the effect of other factors considered essential for economic growth, such as investment in technology (Romer, 1990; Aghion and Howitt, 1998). As a result, recent contributions have stressed the role of human capital in explaining growth differences across countries (Krueger and Lindahl, 2001; Bassanini and Scarpetta, 2002; Engelbrecht, 2003) and across regions within countries (Cheshire and Magrini, 2000; Fingleton, 2004).

Theoretical literature (Note 2) identifies two ways in which human capital can contribute to growth process. First, human capital can directly participate in production as a productive factor. In this sense, the accumulation of human capital would directly generate the growth of output. This is the so-called level effect. Second, human capital can contribute to raising technical progress since education eases the innovation, diffusion and adoption of new technologies. In this way, the level of human capital affects productivity growth. This second effect is the so-called rate effect (Freire-Seren, 2001).

Although there have been an extensive empirical studies focusing on modelling and analyzing the impact of human capital on economic growth in developed economies, little attention has been paid in developing countries, and to the best of our knowledge, empirical research on the topic is fragmented as there is few works that attempt to investigate the issue for Sudanese economy. Thus, one of the contributions of this paper is to provide empirical evidence on the topic for Sudan economy. The paper also offers a methodological contribution by investigating the impact of human 
capital on economic growth not only under the single equation estimation but also by taking into account the simultaneous effect between the variables

The motivation for this paper comes from different sources; first: economic development plans in Sudan were founded on the idea of investing in physical plants and infrastructure and did not give development of human capital a high priority, second: Labor force needs were not spelled out, nor were they based on realistic estimates of the skill requirement and third, Sudan has expanded schooling opportunities without seeing any dramatic catch-up with developed countries in terms of economic well-being instead poverty has been spreading and the medium class has been eroding.

The main purpose of this paper is to empirically measure and analyze the impact of human capital on economic growth in Sudan during the period of 1982-2009. The remainder of the paper is structured as follows. Section 2 presents a review of the theoretical and empirical literature on human capital and growth. Section 3 describes the data, while Section 4 presents the econometric framework and methodology. In Section 5, estimation results are analyzed, while Section 6 concludes the paper

\section{Literature Review}

Over the years there has been an extensive research work that examines the contribution of human capital in the growth process for both developed and developing economies. Barro (1991) found that primary and secondary enrolment rates have a positive growth effect, but this was not always true for adult literacy rates. Barro and Sala-i-Martin (1995) found that the average schooling years have a significant positive impact on the economic output. By applying input-output analysis Jorgenson et.al (2003) studied the sources of growth for the economy of the United States over the period of 1977-2000 and they found that economic growth for the US was dominated by investments in information and higher education. Based on two stages least square Bloom et al. (2004) try to investigate the impact of human capital on economic growth, they find that schooling and life expectancy both positively contribute to economic growth. Improvements in health standards are associated with increase in output due to increased labor productivity and capital accumulation. Musibau and Rasak (2005) have studied long run relationship between education and economic growth in Nigeria. They have used two channels to test the significance of human capital for economic growth. In the first channel, human capital is used as an independent factor of production and in the second channel; human capital affects economic growth through technology parameter. According to their findings, a well-educated labor force significantly affects economic growth through both channels.

More recently, Lee (2010) looks at the impact of education on economic growth of 75 countries during the period 1960-2000 using "conditional dummy" and education attainment for the population aged 15 and above in 1960. The results reveal that education helps to accelerate growth in a cross-section of economies once continental dummies are being controlled for. Based on using the Generalized Methods of Moments (GMM), Zhang and Zhuang (2011) examined the effect of the composition of human capital on economic growth in China the results showed that tertiary education had played a more important role than primary and secondary education on economic growth. Moreover, the role of the composition of human capital on regional economic growth is relevant to the level of development. The more developed provinces benefit more from tertiary education, while underdeveloped ones depend more on primary and secondary education.

For the case of Sudan, Nour (2010) employed descriptive and comparative approaches and used the Organization for Economic Cooperation and Development's OECD definition of science and technology S\&T. She found that the low level and inefficient financial and human resources devoted to S\&T together with inadequate economic structure; meaning that Sudan lags behind leading developing countries in terms of S\&T input-output indicators. Moreover, insufficient financial and human resources hampered the potential role of R\&D to contribute towards development, adaptation to imported technologies and development of local technology.

\section{Data Description}

The data used for investigating the impact of human capital on Sudanese economic growth span the period 1982 to 2009 and are taken from different sources. Data symbols, description and sources are depicted in Table 1. 
Table 1. Variables included, their description and sources 1982-2009

\begin{tabular}{llll}
\hline Variable & Symbol & Description & Source \\
\hline Real Gross Domestic Product & Y & Million Sudanese Pounds & Central Bureau of Statistics \\
Gross Domestic Product & GDP & Million Sudanese Pounds & Central Bureau of Statistics \\
Consumer Price Index & CPI & Annual & Central Bureau of Statistics \\
Total Population & POP & Million Persons & Central Bureau of Statistics \\
Per Capita GDP & Q & Million Sudanese Pounds & Central Bureau of Statistics \\
Capital Stock & K & Million Sudanese Pounds & Central Bureau of Statistics \\
Teacher-Pupil Ratio & PRM & Basic Education & Central Bureau of Statistics \\
Doctor-100000 Population & DOC & Number & Central Bureau of Statistics \\
Electricity Consumption / person & ELEC & ratio & Central Bureau of Statistics \\
Total Number of Crimes & crime & Integer & Central Bureau of Statistics \\
Fixed and Mobile Phones & Mob & Ratio to 000 Population & Central Bureau of Statistics \\
Total Government Expenditure & GX & Million Sudanese Pounds & Ministry of Finance \\
States Total Expenditure & GXS & Million Sudanese Pounds & Ministry of Finance \\
Foreign Direct Investment & FDI & Million Sudanese Pounds & Ministry of Investment \\
Human Development Index & HDI & Percentage & UNDP \\
spending on Education and Health & HC & Ratio to GDP & CBS and Ministry of Finance \\
World Consumer Price Index & WCPI & Percentage & IMF Year Book \\
\hline Constructed Variables & & & \\
\hline Total Factor Productivity & TFP & Million Sudanese Pounds & Own Calculation \\
Labor Force & LABF & Million Worker & Interpolation from CBS data \\
School Attainment & SCH & Years & Interpolation from Barro data \\
\hline
\end{tabular}

Table 2 contains the data's summary statistics.

Table 2. Summary statistics

\begin{tabular}{llllllllll}
\hline & Mean & Median & Max. & Min. & Std. Dev. & & & Skewness & Kurtosis \\
& & & & & & Jarque-Bera & \\
\hline Q1 & 498 & 495 & 586 & 412 & 60 & 0 & 2 & 0.80 & 0.67 \\
K & 39204 & 39528 & 47947 & 30436 & 6105 & 0 & 2 & 0.78 & 0.68 \\
LABF & 11 & 11 & 13 & 9 & 2 & 0 & 2 & 0.88 & 0.65 \\
TFP & 30840 & 31006 & 40031 & 20868 & 6901 & 0 & 2 & 0.87 & 0.65 \\
GX & 11054215 & 7361000 & 29738000 & 1673361 & 9343755 & 1 & 2 & 1.41 & 0.49 \\
GXS & 2582225 & 2241904 & 5129730 & 829357 & 1480412 & 1 & 2 & 1.05 & 0.59 \\
POP & 34 & 34 & 38 & 29 & 3 & 0 & 2 & 0.68 & 0.71 \\
SCH & 2.85 & 2.87 & 3.04 & 2.65 & 0.13 & -0.28 & 2.15 & 0.34819 & 0.84 \\
PRM & 29.13 & 28.50 & 34.00 & 27.00 & 2.17 & 1.54 & 4.37 & 3.79087 & 0.15 \\
DOC & 17.73 & 17.50 & 22.60 & 14.60 & 2.64 & 0.62 & 2.49 & 0.60266 & 0.74 \\
HC & 2.35 & 2.20 & 6.18 & 0.00 & 1.80 & 1.08 & 3.91 & 1.82169 & 0.40 \\
HDI & 0.50 & 0.50 & 0.53 & 0.48 & 0.02 & -0.33 & 1.99 & 0.48162 & 0.79 \\
FDIK/Y & 0.07 & 0.06 & 0.14 & 0.03 & 0.04 & 0.99 & 2.73 & 1.32400 & 0.52 \\
\hline
\end{tabular}

\section{Theoretical and Empirical Framework}

In this section, we develop an empirical model to ascertain the impact of human capital on economic growth in Sudan. The proposed model is composed of six equations containing 19 variables for the period 1982-2009. The methodology used is the estimation of simultaneous equation model that links human capital i.e. school attainment; and investment in education and health to economic growth, total productivity, foreign direct investment, and human development index.

\subsection{School Attainment}

Most attention to the value of schooling focuses on the economic returns to differing levels of school attainment for individuals. Studies have uniformly shown more schooling is associated with higher individual earnings.

Each generation learns from previous generations; the ability to build on the human capital of one's elder plays an important role in the growth generated by the time spent in school. The relationship between schooling and economic 
growth reflects reverse causality, that is, schooling could respond to the anticipated rate of growth for income (Bils and Klenow 2004).

$$
s c h_{t}=\beta_{1} q_{t}+\beta_{2}\left(\frac{k}{l a b f}\right)_{t}
$$

\subsection{Economic Growth}

The growth accounting analysis (GAA) of neoclassical based on Solow's growth model determines the ratios of major inputs arithmetically. Technology ratio is computed by extracting ratios of labor and capital from the total output growth rate (Lee and $\mathrm{Yu}$ 1998). GAA generally assumes that the Solow residuals capture total factor productivity growth. Endogenous growth theory in particular endogenous technology change model (ETCM) regards technological change and human capital as endogenous and core factors of economic growth. Theoretical models of economic growth have emphasized different mechanism through which education may affect economic growth; stressing respectively the role of education as a production factor that be accumulated, increasing the innovative capacity of the economy, and facilitating the transformation of knowledge needed to implement new technologies (Hanushek and Woessmann 2012).

$$
q_{t}=\beta_{3} s c h_{t}+\beta_{4} t f p_{t}+\beta_{5} \text { prm }_{t}
$$

\subsection{Foreign Direct Investment}

Many governments want to attract FDI because of the perception that the potential positive effects of FDI (growth, technology, skill upgrading and capital) generally outweigh its negative effects (income inequality, environmental problems). FDI affects the distribution of wages, in turn human capital is a major determinant of wage distribution, employment quality, employment quantity and FDI can affect both terms (Velde 2001). To attain the goals of economic plans the government has to seek ways to increase revenues such as levying taxes and fees this causes hostile regulatory environment that may have adverse effects on investment environment. Moreover, directing spending towards consumption activities rather than productive ones affects infrastructure and the availability of information negatively; both are discouraging factors. Electricity consumption per person can be used as a proxy for infrastructure and it is one of World Bank Development indicators

$$
\left(\frac{f d i}{g d p}\right)_{t}=\beta_{6}\left(\frac{g x}{g d p}\right)_{t}+\beta_{7} q_{t}+\beta_{8} h c_{t}++\beta_{9} \text { Elecr }_{t}
$$

\subsection{Total Factor Productivity}

Endogenous economic theory has paid most attention on endogenous policy factor rather than external factors. Growth of total factor productivity (TFP) provides the dominant source of output growth. The decomposition of output growth demonstrates that factor growth generally proves much more important than either the improved quality of factors or total factor productivity growth in explaining output growth (Limam and Miller 2004). The secrets of long-run economic growth are rigorously defining TFP and finding policies and institutions most conducive to TFP growth (Easterly and Levine 2001).

Total factor productivity only increases if people work smarter and learn to obtain more output from a given supply of inputs. Improvements in technology clearly increase the total factor productivity (Law 2000). Both theory and recent empirical evidence have demonstrated that income distribution does in fact have significant impact on the growth process. Income distribution has a long lasting effect on investment on human capital, aggregate income, and economic development. Moreover unlike the classical view point which underlined the beneficial effects of inequality for the growth process, the modern perspective highlighted the potential adverse effects of inequality on the growth process (Galor 2009). Globalization and the rise of information and communication technologies driven the need for development and technology as an essential factor for improving social development, the quality of live and the global environment (Nour 2010). The long-term rate of growth of technology will be slowed by anything that slows either the development of new technology or the rate at which new technology embodied through investment (such as uncertainty, high interest rates) (Lipsey 2001). Since interest rate is prohibited by Shariea (Note 3) laws in Sudan relative price is taken as a proxy. Other factors can be considered as the dependency on foreign technology measured by the share of chemicals, manufactured goods, machinery and equipment, transport equipment, and petroleum products to imports of goods.

$$
t f p_{t}=\beta_{10} q_{t}+\beta_{11}\left(\frac{c p i}{w c p i}\right)_{t}+\beta_{12} h c_{t}
$$




\subsection{Human Development Index}

The Human Development Index (HDI) is a composite statistic used to rank countries by level of "human development", taken as a synonym of the older terms "standard of living" and/or "quality of life", and distinguishing "very high human development", "high human development", "medium human development", and "low human development" countries. The explicit purpose of HDI is to shift the focus of development economics from national income accounting to people centered policies. Economic resources provide material basis for improved human development, but human development (health and education of population) is essential inputs into economic growth. Sen has shifted the analysis of development to the vector of not only attributes e.g. income, education, health, but also the vector of possible opportunities available to individuals in particular state. Opportunities are affected by the certain attributes of individual: starving or uneducated would have fewer chances than a healthy (Gustav 2004).

\subsection{Investment in Education and Health}

$$
h d i_{t}=\beta_{13} s c h_{t}+\beta_{14} d o c_{t}+\beta_{15} t f p_{t}+\beta_{16} q_{t}
$$

Investment in education increase labor force capacity to produce. Because better-educated workers are more literate and numerate, they should be easier to train, and to learn more complex tasks, better work habits in terms of awareness of time and dependability. Human capital is mainly influenced by social capital. Social capital is like a filter through which human and financial capital flow from the parents and community to child producing better educational outcomes. Social capital can be represented by: rising crime rates, declining family and kinship cohesion, distress, and mortality rates, life expectancy, dummy variables of: rule of law, court system, political liberates, corruption, political instability. Human capital can be increased by investing in education, health care, and job training. Education causes an individual to earn more and become productive; therefore a rise in the average level of education of the nation's workforce would be expected to increase national income (Parts 2003). War affects human capital adversely since most of the resources are devoted to military expenditure human capital development suffers at the expense of military expenditures (looney 1992). Expenditure devoted to security can be beneficial to economic development if there is a mix between hardware and personnel development. Technical skills gained by soldiers are of particular value for economic development. Health is one of the most important assets of human being has. Healthy individuals are more efficient at assimilating knowledge and in consequences obtain higher productivity levels. Productivity of labor depends on factors like physical and mental capabilities. Improvements in health could affect labor productivity by raising the experience level of the work force and increasing man-hours of work. Also labor productivity could be reduced by the need to care for sick relatives or by reducing the year of schooling if the parents are chronologically ill (Rico et al 2005). Health capital enters models as a significant variable for economic growth. It has been observed that countries with level of education have higher rate of returns to schooling exhibiting diminishing returns.

$$
h c_{t}=\beta_{17} \operatorname{popg}_{t}+\beta_{18}\left(\frac{g x S}{g x}\right)_{t}+\beta_{19} \text { prm }_{t}+\beta_{19} \text { war }_{t}
$$

\subsection{Other Factors}

Life expectancy is the most used variable to represent it. Distinction is made between proximate (accumulation of capital, labor and technology), and ultimate (legal and political systems, socio-cultural factors, demography and geography) sources of growth (Petrakos et al 2007). The link between geography and economic activity is obvious. Geographic data i.e. distance to economic centers, location of districts, and clustering of economic activity are of great importance for economic growth. Distance matters in economic development, far from economic centers is disadvantageous for regions, they lose their opportunity to access core markets. Geographical location influence is through flows of goods, factors of production and ideas. Spatial clustering may have negative impact due to outflow of resources from poor regions to their neighbors that have better economic performance, and decentralization can lead to the competition among regions.

The first step in model estimation is to calculate the capital stock, labor force. Capital stock series is constructed applying the Perpetual Inventory Method (calculating the ending stock on continuous basis after each transaction); the benchmark net capital sock for the base year 1980 is 32123, and assuming 5\% depreciation rate of fixed capital 0.05. Labor force is interpolated from census data provided by CBS. Standard Cobb-Douglas model was estimated in its nonlinear form to obtain estimated coefficient of 0.3 and 0.77 for labor force and capital respectively (annex 1). Wald test accepted the hypothesis of unity sum of labor and capital stock coefficients (annex 2). Total factor productivity was calculated by dividing real GDP by the product of labor force raised to its estimated coefficient by capital raised to its estimated coefficient. 


\section{Empirical Results and Discussions}

\subsection{Empirical Results}

The first step in model estimation is to calculate the capital stock, labor force. Capital stock series is constructed applying the Perpetual Inventory Method (calculating the ending stock on continuous basis after each transaction), the benchmark net capital sock for the base year 1980 is 32123, and assuming 5\% depreciation rate of fixed capital 0.05. Labor force is interpolated from census data provided by CBS. Standard Cobb-Douglas model was estimated in its nonlinear form to obtain estimated coefficient of 0.514 and 0518 for labor force and capital respectively. Wald test accepted the hypothesis of unity sum of labor and capital stock coefficients (annex 2). Total factor productivity was calculated by dividing real GDP by the product of labor force raised to its estimated coefficient by capital raised to its estimated coefficient.

$$
\begin{array}{ccc}
\mathrm{SCH}=1.62 * \mathrm{Q} 1+0.0006 * \mathrm{~K} / \mathrm{LABF}+[\mathrm{AR}(1)=0.8907] \\
\mathrm{t}=4.5 & 6.4 & 47.7 \\
R^{2}=0.98 & \bar{R}^{2}=0.97 & D W=2.1
\end{array}
$$

School attainment responded positively to the anticipated rate of growth of income. As income increases by one unit years of schooling increase by 1.62 since those who attain high level of education will be rewarded with high payment and hence better life style. The positive response of school attainment to capital-labor ratio as well, is as expected since the rise of capital ratio to labor requires knowledge to deal with technology and one unit rise in the ratio raise years of schooling approximately by 0.001 . Thus the economic criterion is met. The individual estimates are statistically significance since the estimated $t$ each statistic is greater than the tabulated one i.e. 1.72. The explanatory variables explain ninety seven percent of the schooling total variation. Hence the statistical criterion is satisfied. The model initially suffered from the existence of autocorrelation which was correct by Cochran-Orcutt method.

$$
\begin{array}{rrc}
\mathrm{Q} 1=0.0709 * \mathrm{SCH}-0.0000002 * \mathrm{TFP}-0.0326 * \mathrm{PRM} \\
\mathrm{t}=25.1 & 28.5 & 7.6 \\
R^{2}=0.74 & \bar{R}^{2}=0.8 & D W=2.1
\end{array}
$$

Quantity and quality of education i.e. school attainment and teacher-pupil ratio at the primary level of education affect economic growth positively. Total factor productivity has not got the anticipated positive sign this due to the obsolete and old fashion technology used in production. One unit of schooling is associated with 0.1 unit increase in economic growth. All the estimated coefficients are statically different from zero since their individual $t$ values are greater than 0.181 . No autocorrelation is encountered. Eighty percent of the model total variations are explained by the education and factor productivity.

$$
\begin{aligned}
& \mathrm{FDIR}=-2.067 * \mathrm{GX} / \mathrm{GDP}+0.4334 * \mathrm{Q} 1-0.0141 * \mathrm{HC}+2.6777 * \mathrm{ELECR} \\
& \begin{array}{lllll}
\mathrm{t} & =-7.5 & 10.7 & -7.1 & 3.9
\end{array} \\
& R^{2}=0.83 \quad \bar{R}^{2}=0.71 \quad D W=2.12
\end{aligned}
$$

The adverse effect of the ratio of government total expenditure to GDP on the ratio of foreign direct investment to GDP can be attributed to the concentration of the governments on consumption activities rather than productive activities. The bulk of expenses are directed towards security and privileged politicians. Development has low priority, the consequences are inferior infrastructure, and this in turn does not encourage foreign investors to come. On the contrary an increase in per capita attracts more foreign direct investment. In relation to the government expenditure investment in education and health (human capital) receives low share of total expenditure FDI affects the distribution of wages, in turn human capital is a major determinant of wage distribution, employment quality, employment quantity so human capital affects FDI the wage channel. All coefficients are statistically different from zero since the estimated $\mathrm{t}$-value is greater than

$$
\mathrm{TFP}=827277.8 * \mathrm{Q} 1+30.2442 * \mathrm{CPI} / \mathrm{WCPI}-6667.762 * \mathrm{HC}
$$

$$
R^{2}=0.99 \quad \bar{R}^{2}=0.97 \quad D W=2.27
$$


The relation between TFP and growth is a positive one. Results have shown a negative sign which can be attributed to inequality which results from income distributing income. Income growth will not be beneficial to TFP growth if a large portion of it is directed toward consumption activities rather than modernizing technology and productive capacity of the economy. Less investment in education and health will definitely adversely affect TFP. Much new technological knowledge is embodied in capital equipment whose accumulation is measured as gross investment, so technological change and investment are interrelated. The latter being the vehicle by which the former enters the production process.

$$
\begin{aligned}
& \mathrm{HDI}=0.8308 * \mathrm{SCH}+0.000521 * \mathrm{DOC}-0.000000193-06 * \mathrm{TFP}+0.786519 * \mathrm{Q} 1 \\
& \begin{array}{lllll}
\mathrm{t} & =4.5 & 3.2 & -3.9 & 2.3
\end{array} \\
& R^{2}=0.94 \quad \bar{R}^{2}=0.93 \quad D W=1.54
\end{aligned}
$$

The signs of the estimated coefficients of year of schooling (education), and the health quality factor number of doctors to 100000 persons are positive as expected. The probability of opportunities available to individuals increases with increase of per capita income and thus affects human development positively. Total factor productivity which mainly represents the state of technology has adverse effect on human development due to the obsolete and old fashion technology. Economic, statistical and econometric criteria are met.

$$
\begin{array}{cccc}
\mathrm{HC}= & 147.5289 * \mathrm{POPG}-2.652219 * \mathrm{GXS} / \mathrm{GX}+1.38598 * \mathrm{WAR} \\
\mathrm{t} \quad=3.5 & -6.3 & -2.6 & 3.3 \\
R^{2}=0.54 & \bar{R}^{2}=0.50 & D W=3.05
\end{array}
$$

Population growth leads to the need for more investment in education and health. States' governments are responsible for spending on basic and secondary education. The states resemble the central government in their priorities of spending. They receive support from the central government for current and development spending. Low investment in education leads to slow rat of school construction and low recruitment of teachers which in turn causing crowded classes and less benefits from the education process. Expenditure devoted to security can be beneficial for economic development if there is a mix between hardware and personnel development.

\subsection{Discussion}

The primary focus of Sudan has been finding a way to accelerate rate of growth of national income and to engage in restructuring the economy. Economic development plans in Sudan were founded on the idea of investing in physical plants and infrastructure and did not give development of human capital a high priority in addition to that; Labor force needs were not spelled out. In spite of all abundant resources, Sudan has failed to realize its full development potential i.e. sustainable human capital development. Policies for direct investment are not sufficient for generating economic development and new policies such as improving inputs or new skill-intensive operations should be design to make FDI work for development. The government needs to build institutions in order to address market failure associated with the process of FDI.

The current situation in Sudan is that the illiteracy rate is very high, most of the workers are unskilled and they make use of outmoded capital equipment and methods of production. By implication their marginal productivity is extremely low, and this leads to low real income and low saving, low investment, and consequently low capital formation.

The long-term rate of growth of technology has been slowing by many factors the most influential are uncertainty caused by exchange and inflation rates (Arabi 2012, 2011). Moreover, insufficient financial and human resources which are central to research and technological innovation activities hampered the potential role of R\&D to contribute towards development, adaptation to imported technologies and development of local technology, the spending share of R\&D as a percentage of GDP is below 1\% (Nour 2010). There is a lack of interaction between various institutions dealing with $\mathrm{S} \& \mathrm{~T}$ as well with higher education, innovation and technology diffusion. The average and median of the dependency ratio on foreign technology are 0.84 and 0,85 respectively.

\section{Conclusion}

The main objective of this paper was to investigate the impact of human Capital on economic growth for Sudan over the period of 1982-2009 by using a simultaneous equation model that links human capital i.e. school attainment; and 
investment in education and health to economic growth, total productivity, foreign direct investment, and human development index. The empirical results of the paper show the following; first the quality of the education has a determinant role in the economic growth, the highly educated people are influencing more the economic output than the secondary educated ones. Second, there is an adverse effect of the ratio of government total expenditure to GDP on the ratio of foreign direct investment to GDP which can be attributed to the concentration of the governments on consumption activities rather than productive activities; third, health quality factor has a positive impact on economic growth as expected

\section{References}

Aghion, P., \& Howitt, P. (1998). Endogenous growth theory. The MIT Press, Cambridge, MA.

Ayub, M. (2007). Understanding Islamic Finance. Chichester, England, John Wiley \& Sons Ltd

Azariadis, C., \& A. Drazen (1990). Threshold externalities in economic development. Quarterly Journal of Economics, 90, 501-526. http://dx.doi.org/10.2307/2937797

Barro, R. (2001). Human capital and growth. American Economic Review, 91, 12-17. http://dx.doi.org/10.1257/aer.91.2.12

Barro, R. J. (1991). Economic Growth in a Cross Section of Countries. Quarterly Journal of Economics, 106(425), 407-43. http://dx.doi.org/10.2307/2937943

Barro, R., \& J. W. Lee. (2010). International Data on Education Attainment: Updates and Implications. Department of Economics, Harvard University data set. Retrieved from http/www.cid.harvard.edu/ciddata

Barro, R., \& Sala-i-Martin, X. (1995). Economic Growth. McGraw-Hill, New York.

Bassanini, A., \& Scarpetta, S. (2002). Does human capital matter for growth in OECD countries? A pooled mean-group approach. Economics Letters, 74, 399-405. http://dx.doi.org/10.1016/S0165-1765(01)00569-9

Becker, Gary S. (1962). Investment in human capital: A theoretical analysis. Journal of Political Economy, 70(Supplement), 9-49. http://dx.doi.org/10.1086/258724

Bils, Mark, \& Klenow, Peter J. (204). Does schooling Cause Growth. The American Economic Review, 90(5), 1160-1183

Bloom, D. E., Canning, D., \& Sevilla, J. (2004). The effects of health on economic growth: A production function approach. World Development, 1-13. http://dx.doi.org/10.1016/j.worlddev.2003.07.002

Brata Aloysius Gunadi. (2009). Does Geographic Factors Determine Local Economic Development. IRSA International Institute.

Chesire, P., \& Magrini, S. (2000). Endogenous Processes in European Regional Growth: Convergence Policy. Growth and Change, 31, 455-480. http://dx.doi.org/10.1111/0017-4815.00140

Easterly William, \& Ross Levine. (2001). It's not Factor Accumulation: Stylized Facts and Growth Models. World Bank.

El-Gamal, M. A. (2006). Islamic Finance: Law, Economics, and Practice. Cambridge, Cambridge University Press. http://dx.doi.org/10.1017/CBO9780511753756

Engelbrecht, H. (2003). Human capital and economic growth: cross-section evidence for OECD countries. Economic Record, 79, 40-51. http://dx.doi.org/10.1111/1475-4932.00090

Fingleton, B. (2004). Some alternative geo-economics for Europe's regions. Journal of Economic Geography, 4, 389-420.

Freire-Seren, M. J. (2001). Human Capital Accumulation and Economic Growth. Investigaciones Economicas, 3, 585-602.

Galor, Oded. (2009). Inequality and Income Development An overview. Brown University

Gustav, Ranis. (2004, May). Human Development and Economic Growth. Yale University Center Discussion Paper NO. 887

Hanushek, Eric A., \& Woessmann Ludger. (2012). Schooling, Educational Achievement, and the Latin American Growth Puzzle. Journal of Development Economics. http://dx.doi.org/10.1080/0953531032000111781 
Jorgenson, D. W., Mun, S. H., \& Kevin, J. S. (2003). Growth of US industries and investments in information technology and higher education. Economic Systems Research, 15, 279-325.

Khalafalla, A. M. Arabi. (2010). Association between Inflation and its Uncertainty. Journal of Business Studies Quarterly, 2(2), 33-56

Khalafalla, A. M. Arabi. (2012). Estimation of Exchange rate Volatility via GARCH Models: case study Sudan 1978-2009. International Journal of Economics and Finance, 10.

Krueger, A. B., \& Lindahl, M. (2001). Education and growth: why and for whom? Journal of Economic Literature, 39, 1101-1136. http://dx.doi.org/10.1257/jel.39.4.1101

Law, M. T. (2000). Productivity and Economic Performance: An Overview of the Issues. Public Policy Sources, 37.

Lee Jonk Won, \& Byoung Gyu Yu. An Endogenous Growth Model Approach to the Korean Economic Growth Factors.

Limam, Yasmina, Reem, \& Stephen, M. Miller. (2004). Explaining Economic Growth: Factor Accumulation, Total Factor Productivity, Growth and Production Efficiency Improvement. University of Nevada.

Lipsey, Richard, G. (2001). What Does Total Factor Productivity Measure. Simon fraser University at Harbour Centre.

Looney, Robert, E. (1992). Economic Development in Iraq: Factors Underlying the Relative Deterioration of Human Capital Formation. Journal of Economic Issues, XXVI(2).

Lucas, R. (1988). On the Mechanics of Economic Development. Journal of Monetary Economics, 22, 3-42. http://dx.doi.org/10.1016/0304-3932(88)90168-7

Mankiw, N.G., Romer, D., \& Weil, D.N. (1992). A contribution to the empirics of economic Growth. Quarterly Journal of Economics, 107, 407-437. http://dx.doi.org/10.2307/2118477

Mincer, Jacob. (1958). Investment in human capital and personal income distribution. Journal of Political Economy, 66(4), 281-302. http://dx.doi.org/10.1086/258055

Musibau, B. A., \& Rasak, A. A. (2005). Long Run Relationship between Education and Economic Growth in Nigeria: Evidence from Johansen's Cointegration Approach. Cornel University, Dakar - Senegal.

Nelson, R., \& Phelps, E. (1966). Investment in humans, technological diffusion, and economic growth. American Economic Review, 56, 69-75.

Nour, Samia Satti Osman Mohamed. (2010, Dec.). Assessment of Science and Technology Indicator in Sudan. United Nation University UNU-MERIT Working Paper Series.

Petrakos, George, Paschalis, Arvanitidis, \& Sotris, Pavleas. (2007). Determinant of Economic Growth: The Experts' View. EU Working Paper.

Rico, Andres, Aguayo, Iris, A., Guerra, \& Ricardo Montes de Oca. (2005, Aug.). Imperial Evidence of the Impact of Health on Economic Growth. Issues in Political Economy, 14.

Romer, P. (1990). Endogenous technological change. Journal of Political Economy, 98, S71-S102. http://dx.doi.org/10.1086/261725

Romer, P. (1990). Human capital and growth: theory and evidence. NBER Working Paper 3173.

Schultz, Theodore W. (1961). Investment in human capital. The American Economic Review, 51, 1-17.

Tarts Eve. (2003). Interrelationship between Human Capital and Social Capital: Implications for Economic Development in Transition Economies. Tartu University.

Velde Dirk Willem. (2001). Government Policies towards Inward Foreign Direct Investment in the Developing Countries: Implication for human capital formation and income inequality. Technical Meeting OECD Development Centre.

Welch, F. (1970). Education in Production. Journal of Political Economy, 78, 35-59. http://dx.doi.org/10.1086/259599

\section{Notes}

Note 1. Human capital, as viewed by economists, involves a process of investment that enhances human labor productivity by means of advances in knowledge and its applications. It specifically involves investment 
expenditures on education, training, health, nutrition, and related factors that increase the productivity of the labor force.

Note 2. See among others; Nelson and Phelps (1966), Welch (1970), Lucas (1988), Azariadis and Drazen (1990) and Romer (1990).

Note 3. Note 8 for a detailed discussion of the Islamic Shariaa principles and its practices on stock exchange see for example, El-Gamal (2006) and Ayub (2007).

\section{Annex 1}

System: SYSSCH

Estimation Method: Three-Stage Least Squares

Date: 09/01/12 Time: 17:32

Sample: 19832005

Included observations: 24

Total system (unbalanced) observations 75

Convergence achieved after: 1 weight matrix, 15 total coef iterations

\begin{tabular}{crrrr}
\hline & Coefficient & Std. Error & t-Statistic & Prob. \\
\hline $\mathrm{C}(1)$ & 1.620026 & 0.676160 & 2.395921 & 0.0200 \\
$\mathrm{C}(2)$ & 0.000622 & 0.000113 & 5.489314 & 0.0000 \\
$\mathrm{C}(21)$ & 0.890745 & 0.022368 & 39.82217 & 0.0000 \\
$\mathrm{C}(3)$ & 0.070946 & 0.006753 & 10.50640 & 0.0000 \\
$\mathrm{C}(4)$ & $2.03 \mathrm{E}-07$ & $1.09 \mathrm{E}-08$ & 18.55198 & 0.0000 \\
$\mathrm{C}(6)$ & 0.001767 & 0.000300 & 5.900284 & 0.0000 \\
$\mathrm{C}(7)$ & -2.148113 & 0.346156 & -6.205612 & 0.0000 \\
$\mathrm{C}(8)$ & 0.419342 & 0.081534 & 5.143128 & 0.0000 \\
$\mathrm{C}(9)$ & -0.013869 & 0.003228 & -4.295982 & 0.0001 \\
$\mathrm{C}(22)$ & 2.943696 & 0.754346 & 3.902315 & 0.0003 \\
$\mathrm{C}(10)$ & 819406.4 & 105246.5 & 7.785591 & 0.0000 \\
$\mathrm{C}(11)$ & 302.2637 & 21.36873 & 14.14515 & 0.0000 \\
$\mathrm{C}(12)$ & -6937.074 & 2589.523 & -2.678900 & 0.0097 \\
$\mathrm{C}(13)$ & 0.094784 & 0.027309 & 3.470810 & 0.0010 \\
$\mathrm{C}(14)$ & 0.000477 & 0.000176 & 2.714970 & 0.0088 \\
$\mathrm{C}(15)$ & $-1.79 \mathrm{E}-07$ & $4.84 \mathrm{E}-08$ & -3.699407 & 0.0005 \\
$\mathrm{C}(16)$ & 0.699521 & 0.214367 & 3.263198 & 0.0019 \\
$\mathrm{C}(17)$ & 141.5150 & 24.92681 & 5.677222 & 0.0000 \\
$\mathrm{C}(18)$ & -2.682750 & 0.638194 & -4.203657 & 0.0001 \\
$\mathrm{C}(19)$ & 1.654921 & 0.815323 & 2.029774 & 0.0472 \\
\hline Determinant residual covariance & & $3.67 \mathrm{E}-08$ & & \\
\hline
\end{tabular}

Equation: $\mathrm{SCH}=\mathrm{C}(1) * \mathrm{Q} 1+\mathrm{C}(2) * \mathrm{~K} / \mathrm{LABF}+[\mathrm{AR}(1)=\mathrm{C}(21)]$

Observations: 23

R-squared

Adjusted R-squared

S.E. of regression

Durbin-Watson stat

$\begin{array}{lll}0.978271 & \text { Mean dependent var } & 2.340000 \\ 0.976098 & \text { S.D. dependent var } & 0.486500 \\ 0.075215 & \text { Sum squared resid } & 0.113145 \\ 2.227055 & & \end{array}$

Equation: $\mathrm{Q} 1=\mathrm{C}(3) * \mathrm{SCH}+\mathrm{C}(4) * \mathrm{TFP}+\mathrm{C}(6) * \mathrm{PRM}$

Observations: 12

Adjusted R-squared

$0.995286 \quad$ Mean dependent var

0.441879

0.994238

S.D. dependent var

0.054054

0.004103

Sum squared resid

0.000152

Durbin-Watson stat

1.676862




\begin{tabular}{llll}
\hline Equation: FDIR $=\mathrm{C}(7) * \mathrm{GX} / \mathrm{GDP}+\mathrm{C}(8) * \mathrm{Q} 1+\mathrm{C}(9) * \mathrm{HC}+\mathrm{C}(22) * \mathrm{ELEC} / \mathrm{POP}$ & \\
\hline Observations: 8 & 0.838736 & Mean dependent var & 0.066945 \\
\hline R-squared & 0.717789 & S.D. dependent var & 0.042440 \\
Adjusted R-squared & 0.022546 & Sum squared resid & 0.002033 \\
S.E. of regression & 2.195753 & & \\
Durbin-Watson stat & & &
\end{tabular}

Equation: $\mathrm{TFP}=\mathrm{C}(10) * \mathrm{Q} 1+\mathrm{C}(11) * \mathrm{CPI} / \mathrm{WCPI}+\mathrm{C}(12) * \mathrm{HC}$

Observations: 8

\begin{tabular}{llll}
\hline R-squared & 0.992186 & Mean dependent var & 1067228. \\
Adjusted R-squared & 0.989061 & S.D. dependent var & 164834.6 \\
S.E. of regression & 17239.97 & Sum squared resid & $1.49 \mathrm{E}+09$ \\
Durbin-Watson stat & 2.272131 & & \\
\hline
\end{tabular}

Equation: $\mathrm{HDI}=\mathrm{C}(13) * \mathrm{SCH}+\mathrm{C}(14) * \mathrm{DOC}+\mathrm{C}(15) * \mathrm{TFP}+\mathrm{C}(16) * \mathrm{Q} 1$

Observations: 16

R-squared

$0.949614 \quad$ Mean dependent var

0.451250

Adjusted R-squared

$0.937017 \quad$ S.D. dependent var

0.048073

S.E. of regression

0.012065

Durbin-Watson stat

1.536892

Equation: $\mathrm{HC}=\mathrm{C}(17) * \mathrm{POPG}+\mathrm{C}(18) * \mathrm{GXS} / \mathrm{GX}+\mathrm{C}(19) * \mathrm{WAR}$

Observations: 8

\begin{tabular}{llll}
\hline R-squared & 0.545612 & Mean dependent var & 3.348638 \\
Adjusted R-squared & 0.363856 & S.D. dependent var & 1.796836 \\
S.E. of regression & 1.433131 & Sum squared resid & 10.26933 \\
Durbin-Watson stat & 3.053561 & & \\
\hline
\end{tabular}

\begin{tabular}{llllll}
\hline $\mathrm{t}(0.95,8)$ & $\mathrm{t}(0.95,9)$ & $\mathrm{t}(0.95,10)$ & $\mathrm{t}(0.95,11)$ & $\mathrm{t}(0.95,15)$ & $\mathrm{t}(0.95,24)$ \\
\hline 1.86 & 1.83 & 1.81 & 1.796 & 1.753 & 1.711 \\
\hline
\end{tabular}

\section{Annex 2}

Wald Test:

Equation: COBBDOUGLASEQ

Null Hypothesis:

F-statistic

$\mathrm{C}(2)+\mathrm{C}(3)=1$

Chi-square

0.820251

Probability

0.375381

0.820251

Probability

0.365107

